\title{
Accelerated fracture healing with teriparatide
}

João Lindolfo C. Borges

$\mathrm{O}$ n December 2, 2013, it was called our attention that the case report (1) contained few paragraphs that bear a likeness to a further review (2). This occurred inadvertently when we entrusted the literature and a draft of this review (2) to others co-authors. Although we were not aware of theses similarities between the case report and this review. We nevertheless take full responsibility for this error.

The primary objective of our case report $(1)$ is to describe a accelerated fracture healing with teriparatide. It thus is completely different in focus, content, and scope from Goldhahn and cols. review (2). We deeply regret this error and apologize for it to all ABE\&M readership.

\section{REFERENCES}

1. Borges JLC, Freitas A, Bilezikian JP. Accelerated fracture healing with teriparatide. Arq Bras Endocrinol Metab. 2013;57(2):153-6.

2. Goldhahn J, Feron JM, Kanis J, Papalous S, Reginster JY, Rizzoli R, et al. Implications for fracture healing of current and new osteoporosis treatments: an ESCEO consensus paper. Calcif Tissue Int. 2012;90(5):343-53.

1 Universidade Católica de Brasília (UCB), Brasília, DF, Brazil

Correspondence to:

João Lindolfo C. Borges

SHIS QI 09, Centro Clínico

do Lago, Sala 207

71625-009 - Brasília, DF, Brazil

jlborges@metabolismo.com.br

Received on Jan/15/2015

Accepted on Jan/15/2015

DOI: 10.1590/2359-3997000000016 